University of Nebraska - Lincoln

DigitalCommons@University of Nebraska - Lincoln

Publications from USDA-ARS / UNL Faculty

U.S. Department of Agriculture: Agricultural

Research Service, Lincoln, Nebraska

2000

Transgenic avidin maize is resistant to storage insect pests

\author{
Karl J. Kramer \\ USDA-ARS, kramer@usgmrl.ksu.edu \\ Thomas D. Morgan \\ USDA-ARS \\ James E. Throne \\ USDA-ARS, Manhattan, KS, james.throne@ars.usda.gov \\ Floyd E. Dowell \\ USDA-ARS \\ Michele Bailey \\ ProdiGene, Inc.
}

See next page for additional authors

Follow this and additional works at: https://digitalcommons.unl.edu/usdaarsfacpub

Kramer, Karl J.; Morgan, Thomas D.; Throne, James E.; Dowell, Floyd E.; Bailey, Michele; and Howard, John A., "Transgenic avidin maize is resistant to storage insect pests" (2000). Publications from USDA-ARS / UNL Faculty. 2053.

https://digitalcommons.unl.edu/usdaarsfacpub/2053

This Article is brought to you for free and open access by the U.S. Department of Agriculture: Agricultural Research Service, Lincoln, Nebraska at DigitalCommons@University of Nebraska - Lincoln. It has been accepted for inclusion in Publications from USDA-ARS / UNL Faculty by an authorized administrator of DigitalCommons@University of Nebraska - Lincoln. 


\section{Authors}

Karl J. Kramer, Thomas D. Morgan, James E. Throne, Floyd E. Dowell, Michele Bailey, and John A. Howard 


\title{
Transgenic avidin maize is resistant to storage insect pests
}

\author{
Karl J. Kramer ${ }^{1 *}$, Thomas D. Morgan¹, James E. Throne1, Floyd E. Dowell', Michele Bailey², and John A. Howard² \\ ${ }^{1}$ Grain Marketing and Production Research Center, Agricultural Research Service, US Department of Agriculture, Manhattan, KS 66502. ${ }^{2}$ ProdiGene, Inc., 101 \\ Gateway Boulevard, College Station, TX 77845. ${ }^{*}$ Corresponding author (kramer@usgmrl.ksu.edu).
}

Received 13 January 2000; accepted 7 March 2000

\begin{abstract}
Avidin is a glycoprotein found in chicken egg white, that sequesters the vitamin biotin. Here we show that when present in maize at levels of $\geq 100$ p.p.m., avidin is toxic to and prevents development of insects that damage grains during storage. Insect toxicity is caused by a biotin deficiency, as shown by prevention of toxicity with biotin supplementation. The avidin maize is not, however, toxic to mice when administered as the sole component of their diet for 21 days. These data suggest that avidin expression in food or feed grain crops can be used as a biopesticide against a spectrum of stored-product insect pests.
\end{abstract}

Keywords: genetic engineering, insect biology, stored grain, insect resistance, corn, host plant resistance, biotin, transgenic plants, NIR

After harvest, maize and commodities produced from maize are frequently hosts to a great variety of insect and fungal pests that cause severe economic damage ${ }^{1-6}$. Although $B t$ formulations have been evaluated extensively for controlling insect pests of stored grain, commercially acceptable levels of protection against coleopteran (beetle) pests have not been achieved ${ }^{7-10}$. In addition, the development of insect resistance to these naturally occurring toxins is a concern ${ }^{11}$, prompting efforts to discover other insecticidal proteins.

Previously we reported that avidin, a chicken (Gallus gallus) glycoprotein composed of four glycosylated subunits ${ }^{12-14}$, is toxic to seven species of stored-product beetles (Coleoptera) and moths (Lepidoptera) ${ }^{15}$. Avidin and a related protein, streptavidin, produced by the bacterium Streptomyces avidinii, exhibit one of the highest known affinities in nature between a protein and their ligand, biotin $\left(\mathrm{K}_{\mathrm{a}}=10^{15} \mathrm{M}^{-1}\right)$. Biotin is a coenzyme required for all forms of life, so feeding avidin or streptavidin to many insects causes a biotin deficiency that leads to stunted growth and mortality. Avidin also is toxic to the house fly (Musca domestica ${ }^{16}$ ), hide beetle (Dermestes maculatus ${ }^{17}$ ), olive fruit fly (Dacus oleae ${ }^{18}$ ), fruit fly (Drosophila melanogaster ${ }^{19}$ ), flour mite (Acarus siro ${ }^{20}$ ), European corn borer (Ostrinia nubilalis ${ }^{15}$ ), and tobacco hornworm (Manduca sexta ${ }^{21}$ ).

Recently, the first commercial production of avidin in transgenic maize was described ${ }^{22}$. Avidin is used in a variety of biochemical and diagnostic procedures, and its cost is greatly reduced by production in transgenic plants. Based on the retail price of the purified protein, the transgenic maize has an estimated worth of about $\$ 5$ million per hectare ${ }^{23}$. The susceptibility of this crop to stored-product insects has not been examined until now. Here we report that avidin maize is highly resistant toward many species of stored-product insect pests ${ }^{15}$.

\section{Results}

ELISA and near-infrared spectroscopy (NIRS) analysis of avidin concentration in maize. ELISA of extracts of individual kernels of avidin maize revealed that the avidin concentration was highly variable, with levels ranging from 0 to $\sim 2,500$ p.p.m. In one sample of 92 individual kernels, the mean concentration of avidin was $164 \pm 34$ p.p.m. In theory, $50 \%$ of the kernels should not contain avidin, since the avidin-expressing plants were male sterile ${ }^{22}$.
We investigated whether NIRS of single kernels could be used to identify transgenic kernels containing high levels of avidin, using a nondestructive method of analysis. By comparing NIR spectra of 200 single kernels with quantitation of avidin by ELISA, we developed a calibration model (7 factors) to predict avidin concentrations. The analysis showed that $92 \%$ of kernels with $\geq 60$ p.p.m. avidin were correctly classified by the NIRS prediction model as containing significant levels of avidin, whereas $77 \%$ of kernels with $<60$ p.p.m. were correctly identified as containing low levels of avidin. Although the prediction of actual avidin levels in individual kernels was poor $\left(\mathrm{r}^{2}=0.29\right.$, standard error of cross validation $(\mathrm{SECV})=526$ p.p.m. $)$, the average avidin level in those kernels predicted as containing high or low levels of avidin was about 800 and 65 p.p.m., respectively.

Bioassays using whole kernels. The maize weevil, Sitophilus zeamais, was added to transgenic avidin and nontransgenic maize kernels. Overall, mortality was significantly higher on transgenic maize, compared with nontransgenic maize ( $21 \pm 2 \%$ vs. $5 \pm 1 \%$, respectively, $p<0.01)$. Visual inspection and $\mathrm{x}$-ray analysis were used to identify infested kernels, which had a mean avidin concentration of $163 \pm 27$ p.p.m. ( $n=3$ replications, total number of kernels $=149$ ). There was approximately $7 \%$ mortality in kernels with $\leq 10$ p.p.m. avidin (78\% of infested kernels), 53\% mortality in kernels with 11-20 p.p.m. (7\% of infested kernels), and 96\% mortality in kernels with $21-2,500$ p.p.m. (15\% of infested kernels). There was no mortality in kernels with low avidin (0-2 p.p.m.) and 100\% mortality in those with $>300$ p.p.m. These data indicated that overall mortality was greatly influenced by the high proportion of kernels with $\leq 10$ p.p.m. avidin. Probit analysis of the mortality for the weevil as a function of avidin concentration in individual kernels yielded $\mathrm{LC}_{50}$ and $\mathrm{LC}_{95}$ values of 30 and 307 p.p.m., respectively (Table 1).

Newly hatched larvae of the Angoumois grain moth, Sitotroga cerealella, were introduced into maize kernels (Table 1). We found 51 kernels with $<20$ p.p.m. avidin with emergence holes for adults, whereas 3 contained larvae that failed to pupate. Of kernels with 96-1,145 p.p.m. avidin, 13 had larvae inside, but none of these developed into pupae. Dissection of kernels from a similar experiment revealed that approximately $30 \%$ of the infested kernels without emergence holes contained live larvae, and thir growth was probably suspended. Probit analysis yielded $\mathrm{EC}_{50}$ and $\mathrm{EC}_{95}$ val- 


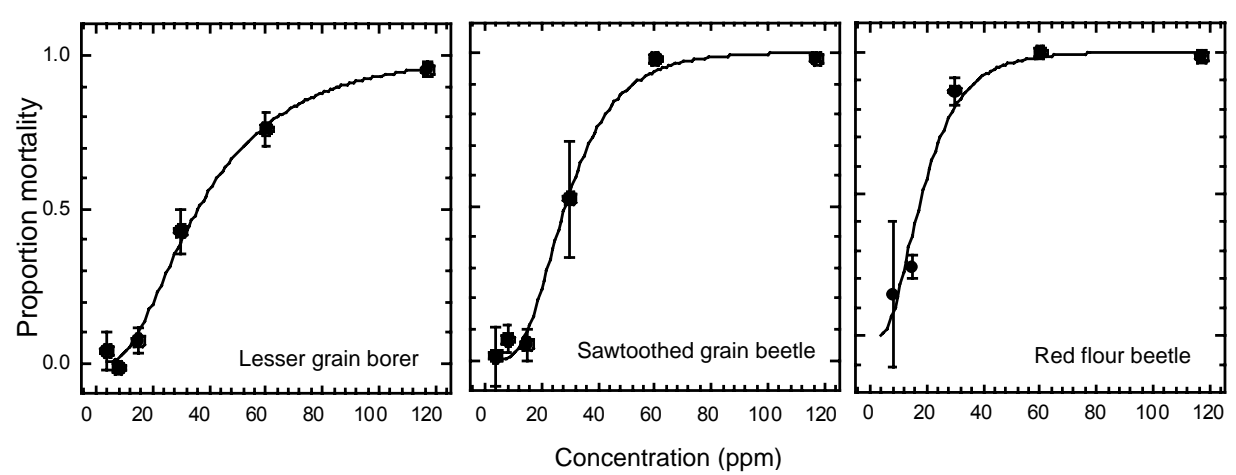

Figure 1. Mortality of three species of Coleoptera as a function of avidin concentration in maize meal: lesser grain borer (Rhyzopertha dominica), sawtoothed grain beetle (Oryzaephilus surinamensis), and red flour beetle (Tribolium castaneum). Data are mean values \pm s.e. from three replicates. Lines are from fitted probit equations. Details are included in the Experimental Protocol.

ues of 36 and 274 p.p.m., respectively, for preventing the development of $S$. cerealella.

Bioassays in ground maize. When reared in groups on cakes of transgenic maize meal with an avidin concentration of 123 p.p.m., the lesser grain borer Rhyzopertha dominica, sawtoothed grain beetle Oryzaephilus surinamensis, and red flour beetle, Tribolium castaneum, had mortalities of $100 \pm 0,99 \pm 1$, and $100 \pm 0 \%$, respectively. When reared on loose meal in groups, the red flour beetle, confused flour beetle Tribolium confusum, and flat grain beetle Cryptolestes pusillus, had $100 \pm 0,98 \pm 2$, and $100 \pm 0 \%$ mortalities, respectively.

Control mortalities for the group bioassays were relatively high (13-31\%), which was caused in part by cannibalism and the failure of some of the eggs to hatch. These variables were eliminated in bioassays of isolated newly hatched larvae of two lepidopteran species. The mortalities of the Indianmeal moth Plodia interpunctel$l a$, and Mediterranean flour moth Anagasta kuehniella, were $95 \pm 5$ and $100 \pm 0 \%$, respectively, on the transgenic meal, whereas the control mortalities on nontransgenic meal were $0 \pm 0$ and $8 \pm 3 \%$, respectively. With the latter species, $20 \pm 5 \%$ of the larvae grew at a normal rate on the control diet but failed to pupate after three months, indicating that they were in diapause.

With the warehouse beetle Trogoderma variabile, we performed bioassays with ground meal from transgenic maize containing either 123 or 265 p.p.m. avidin. Development to the adult stage reached a maximum on meal from the nontransgenic maize by 7 weeks. On the meal from transgenic maize, none of the larvae had pupated by 16 weeks. Our data showed that avidin was highly toxic to the warehouse beetle at 265 p.p.m. and that larval development was greatly suppressed at 123 p.p.m., perhaps as a result of suboptimal nutrition and diapause induction.

The only species examined to date that exhibited a tolerance for avidin was the larger grain borer Prostephanus truncatus. Mortalities were $0 \pm 0 \%$ on transgenic maize, $17 \pm 10 \%$ on control maize, $27 \pm$ $7 \%$ on control maize supplemented with 100 p.p.m. avidin, and $17 \pm$ $10 \%$ on control maize supplemented with 1,000 p.p.m. avidin (not significantly different at $p=0.05, \mathrm{n}=2$ replicates of $14-15$ individuals each). We also recorded the developmental period from egg hatch to adult eclosion, and found that avidin at levels up to 1,000 p.p.m. in ground maize was not toxic to and did not influence the developmental time of this bostrichid beetle.

Concentration-mortality relationships were determined for the lesser grain borer, sawtoothed grain beetle, and red flour beetle using cakes of control maize meal with and without supplementation with avidin (Fig. 1). The groups that were reared on cakes with $\sim 120$ p.p.m. avidin had 96-99\% mortality (Table 1).

In addition to recording the mortality of groups that were reared on cakes of meal, we recorded the mortality of isolated T. castaneum tration/response experiments was not significantly different (relative potency was 0.90 with $95 \%$ confidence limits of $0.79-1.03$ ). These data showed that even though avidin was highly toxic to $T$. castaneum in a diet of maize meal, larval feeding and growth may occur for an extended period of time before death occurs.

Biotin rescue. To determine whether exogenous biotin can prevent the effects of avidin, exogenous biotin was added to the transgenic avidin maize meal and fed to the sawtoothed grain beetle (Table 2 ). Whereas the transgenic maize diet caused $100 \%$ mortality, the addition of only 5 p.p.m. biotin rescued nearly all of the insects. The time from egg hatch to adult eclosion and the weight of adults for insects reared on avidin corn plus biotin were the same as those for insects fed nontransgenic corn.

Mice bioassay. Maize was fed as the sole diet to young adult mice for up to 21 days, during which time the mice were examined for adverse symptoms. Whereas the maize diet was not nutritionally balanced, it nonetheless allowed for a maximum ingestion of 0.5-1.0 mg of avidin per day. Despite the fact that no source of biotin other than corn was given to the mice, the subjects appeared completely normal. The average weight gain per mouse fed 123 p.p.m.-avidin cornmeal for 14 days $(0.86 \pm 1.35 \mathrm{~g})$ was not significantly different from that of mice fed control cornmeal $(0.15 \pm 1.03$ g, Mann-Whitney U-test). Mice fed the more nutritious food in the absence of cornmeal had a higher weight gain $(2.85 \pm 0.72$ $\mathrm{g} /$ mouse). All three of the experimental groups of mice appeared healthy throughout the duration of the experiment. Thus, avidin at $\sim 120$ p.p.m. in maize exhibited no acute oral toxicity to mice that had consumed the transgenic corn for 21 days.

\section{Discussion}

Maize is an important staple crop in many countries ${ }^{24}$. Depending on the climatic and storage conditions, it can become infested by a wide variety of stored-product insect pests ${ }^{25-29}$. Postharvest grain losses caused by pests because of poor storage practices total more than than $\$ 1$ billion per year in the US. A recent survey of storedproduct insects in the US found that weevils, Indianmeal moths, lesser grain borers, and saw-toothed grain beetles caused most the of the problems in processed foods ${ }^{31}$. Avidin-containing maize and its processed products would be resistant to infestations caused by all of the species.

We found that avidin maize has excellent resistance to storage insect pests when the kernels contain a concentration of $>100$ p.p.m. avidin. Many of the kernels used in this study, however, had poor resistance because expression of the protein was not uniform and the majority of the kernels had little or no avidin. Because levels of avidin in individual kernels were widely variable, NIRS was used to rapidly sort kernels into groups containing either high or low levels of avidin. Absorption of NIR radiation at wavelengths 
were used for assays with two species of primary pests: S. zeamais, which penetrates kernels during oviposition, and S. cerealella, which penetrates kernels during initial larval feeding. For S. zeamais, the kernels were equilibrated at $30^{\circ} \mathrm{C}, 12 \mathrm{~h}$ light $/ 12 \mathrm{~h}$ dark photoperiod, and $\sim 75 \%$ relative humidity (RH) over a saturated solution of $\mathrm{NaCl}$. Three replicates of $236 \mathrm{~g}$ of kernels of transgenic maize ( $\sim 810$ kernels) or nontransgenic maize ( $\sim 750$ kernels) were infested with five female adults for $48 \mathrm{~h}^{44}$. The progeny were removed on the day that they emerged as adults. Two weeks after the last adult had emerged, the kernels were examined radiographically to detect any dead larvae and pupae within the kernels. For $S$. cerealella, the kernels were equilibrated at $28^{\circ} \mathrm{C}, 16 \mathrm{~h}$ light $/ 8 \mathrm{~h}$ dark, and $\sim 75 \% \mathrm{RH}$ over a saturated solution of $\mathrm{NaCl}$. Three replicates of 30 neonate larvae were placed on $20 \mathrm{~g}$ of transgenic maize. Emerged moths were removed daily. Two weeks after the last moth had emerged, the kernels were examined radiographically to detect any dead or living larvae inside. The concentration of avidin in each infested kernel was estimated by ELISA.

Bioassays of primary pests using ground maize. Two species of bostrichid beetles, $R$. dominica and $P$. truncatus, are primary pests that can penetrate intact kernels, but they have behavioral characteristics that make them less suitable for bioassays on those kernels. The females of $R$. dominica lay the majority of their eggs outside the kernels, and therefore, the larval diet is often derived from more than one kernel, until each larva finally bores into a kernel to complete its development. Each female of P. truncatus bores into a kernel before laying several eggs in a side tunnel. Because it was difficult to obtain reliable information about the growth and development of these pests on kernels that contained a wide range of avidin concentrations, we used ground maize for bioassay of these species.

Maize kernels were ground through a screen (20 mesh/in.) in a Wiley mill. Rhyzopertha dominica was bioassayed on cakes of this ground maize, because small particles of uncompacted maize were less suitable for the development of the larvae. Ground transgenic or nontransgenic maize (95\%) and wheat gluten $(5 \%)$ were mixed with water in a 1:1.05 ratio (wt/vol) in a $1 \mathrm{oz}$ cup (Solo Cup Co., Urbana, IL). It was compacted into a cake and then the cake was lyophilized. Three cakes of each type of maize were prepared. After equilibration at $28^{\circ} \mathrm{C}, 16 \mathrm{~h}$ light $/ 8 \mathrm{~h}$ dark, and $\sim 75 \% \mathrm{RH}$ over a saturated solution of $\mathrm{NaCl}, 50 \mathrm{R}$. dominica eggs were added to each of the $2.1 \mathrm{~g}$ cakes. Mortalities of the immature stages were recorded from the time of infestation until all of the first generation had either died or developed into adults. For estimation of lethal concentrations of avidin, six control cakes were prepared using water and three cakes of each concentration of avidin were prepared using a solution of homogeneous avidin.

In a preliminary experiment, the mortality of $P$. truncatus on cakes of nontransgenic meal was more than $50 \%$ from the egg to the adult stage. Therefore, we used a second method to bioassay this species. The ground maize meal was compacted to a density of $\sim 0.7 \mathrm{~g} \mathrm{ml}^{-1}$ in $0.2 \mathrm{ml}^{-1}$ microcentrifuge tubes. A newly hatched larva was placed in a small depression in the meal and then loosely covered with a portion of the meal. Each larva was placed on $25 \mathrm{mg}$ of either transgenic or nontransgenic meal that had been slurry mixed with either water or a solution of avidin followed by lyophilization and grinding in a mortar with a pestle (two replicates for a total of 29-30 insects).

Bioassays of secondary pests. Maize cakes were prepared in an identical fashion and tested with two species of secondary pests, O. surinamensis and T. castaneum, that do not attack whole kernels. Either 50 eggs of O. surinamensis or 30 eggs of T. castaneum were placed on the cakes, and the egg-toadult mortality was used to estimate lethal concentrations. We also estimated the lethal concentrations for isolated individuals of T. castaneum. Individual eggs of T. castaneum were placed on $50 \mathrm{mg}$ of maize meal in $1.5 \mathrm{ml}$ microcentrifuge tubes (two replicates of $\sim 20$ eggs).

Several species of secondary pests were also assayed on loose meal, because such pests normally feed on broken kernels and their larval development may be completed more quickly on loose media. Bioassays were performed with three replicates of 25 eggs of C. pusillus or 10 eggs of T. confusum or T. castaneum on $0.5 \mathrm{~g}$ of loose meal in $2 \mathrm{ml}$ tubes. To minimize the incidence of diapause in $T$. variabile, which occurs more frequently when larvae are reared in isolation ${ }^{45,46}$, two replicates of 40 eggs were placed on 8 $\mathrm{g}$ of meal. The pyralid moths, P. interpunctella and A. kuehniella, were assayed as isolated individuals to avoid cannibalism. Each newly hatched larva was placed on $200 \mathrm{mg}$ of diet in $2.0 \mathrm{ml}$ microcentrifuge tubes (two replicates for a total of 40 larvae per treatment per species), and the lids of the tubes were pierced with a \#00 insect pin to provide holes for air exchange.
Biotin rescue. Ground maize was mixed with solutions of biotin (Sigma Chem. Co.) in a 1:1.2 ratio (wt/vol). After lyophilization, the diet was ground using a mortar with a pestle. Individual eggs of $O$. surinamensis were placed on $20 \mathrm{mg}$ of diet in $0.2 \mathrm{ml}$ tubes (two replicates for a total of 17-24 eggs that hatched), and the lids of the tubes were pierced with a pin to provide air exchange. Adult emergence was recorded daily.

Statistical analyses. Means were compared with the MANOVA procedure using the Tukey test of significance ${ }^{47}$. For insect bioassays using whole kernels, PROC LOGISTIC ${ }^{48}$ was used to determine the relationship between mortality and concentration of avidin in kernels because the concentration was measured in each kernel, that is, there were no concentration groups. Confidence limits on LC values were calculated using Fieller's theorem ${ }^{49}$. For insect bioassays in ground maize, POLO PC was used for probit analyses ${ }^{50}$. The Fisher exact test was used to test for significant differences between mortalities of small groups of individuals.

Mice bioassay. Groups of seven ND4 Swiss Webster outbred mice in early adulthood (20-24 g; Harlan Laboratories, Indianapolis, IN) were fed diets of coarsely ground maize meal (5-7 g/day), either transgenic maize seed containing on average 123 p.p.m. avidin or a commercially available nontransgenic maize, continuously for up to 21 days. A third group was fed mouse chow (Teklad Rodent Diet, Harlan Laboratories, Indianapolis, IN).

\section{Acknowledgments}

This paper is dedicated to the memory of Dr. Thomas H. Czapla, a molecular entomologist who was a team member during the early stages of this project. His passion for entomological science was exceptional. We are grateful to Drs. Michael Kanost, Subbaratnam Muthukrishnan, Sonny Ramaswamy, Charles Hedgcoth, Craig Roseland, James Baker, and Troy Weeks for commenting on this manuscript; and Ann Redmon, Trevor Bevans, Natasha Rowly, Feng Xie, Dr. Ian Tizzard and Debra Turner for technical assistance. Mention of a proprietary product does not constitute a recommendation by the USDA. The Agricultural Research Service, USDA, is an equal opportunity/affirmative action employer, and all agency services are available without discrimination.

1. Storey, C.L., Sauer, D.B. \& Walker, D. Insect populations in wheat, corn, and oats stored on the farm. J. Econ. Entomol. 76, 1323-1330 (1983).

2. Sinha, K.K. \& Sinha, A.K. Impact of stored grain pests on seed deterioration and aflatoxin contamination in maize. J. Stored Prod. Res. 28, 211-219 (1992).

3. Cuperus, G. \& Krischik, V. Why stored product integrated pest management is needed. In Stored product management. (Oklahoma State Univ. Coop. Ext. Serv. Circ. E-912, p.199; 1995).

4. Arbogast, R.T. \& Throne, J.E. Insect infestation of farm-stored maize in South Carolina: towards characterization of a habitat. J. Stored Prod. Res. 33, 187-198 (1997).

5. Sedlacek, J.D., Weston, P.A., Price, B.D. \& Rattlingourd, P.L. Survey of insect pests in shelled corn stored on-farm in Kentucky. J. Entomol. Sci. 33, 171-179 (1998).

6. Throne, J.E., Baker, J.E., Messina, F.J., Kramer, K.J. \& Howard, J.A. Varieta resistance. In Alternatives to Pesticides in Stored-Product IPM. (eds Subramanyam, Bh. \& Hagstrum, D.W.) (Kluwer Academic Publishers, Norwell, MA, 2000), in press.

7. Baker, J.E. \& Kramer, K. J. Biotechnological approaches for stored-product insect pest management. Postharvest News Information 7, 11N-18N (1996).

8. Estruch, J.J. et al. Transgenic plants: an emerging approach to pest control. Nat. Biotechnol. 15, 137-141 (1997).

9. Carozzi, N.B. \& Koziel, M.G. Advances in insect control: the role of transgenic plants. (Taylor \& Francis Ltd., London; 1997).

10. Hilder, V.A. \& Boulter, D. Genetic engineering of crop plants for insect resistance-a critical review. Crop Protec. 18, 177-191 (1999).

11. Schnepf, E. et al. Bacillus thuringiensis and its pesticidal crystal proteins. Microbiol. Mol. Biol. Rev. 62, 775-806 (1998).

12. Stevens, L. Egg white proteins. Comp. Biochem. Physiol. 100B, 1-9 (1991).

13. Pugliese, L., Coda, A., Malcovati, M. \& Bolognesi, M. Three-dimensional structure of the tetragonal crystal form of egg-white avidin in its functional complex with biotin at 2.7 A resolution. J. Mol. Biol. 231, 698-710 (1993).

14. Livnah, O., Bayer, E., Wilchek, M. \& Sussman, J. Three-dimensional structures of avidin and the avidin-biotin complex. Proc. Natl. Acad. Sci. USA 90, 5076-5080 (1993).

15. Morgan, T.D., Oppert, B., Czapla, T.H. \& Kramer, K.J. Avidin and streptavidin as insecticidal and growth inhibiting dietary proteins. Entomol. Exp. Appl. 69, 97-108 (1993).

16. Levinson, H.Z. \& Bergmann, E.D. Vitamin deficiencies in the housefly produced by antivitamins. J. Insect Physiol. 3, 293-305 (1959).

17. Levinson, H.Z., Barelkovsky, J. \& Bar Ilan, A.R. Nutritional effects of vitamin omission and antivitamin administration on development and longevity of the hide beetle Dermestes maculatus Deg. (Coleoptera, Dermestidae). J. Stored Prod. Res. 3, 345-352 (1967).

18. Tsiropoulos, G.R. Dietary administration of antivitamins affected the survival and reproduction of Dacus oleae. Z. Ang. Entomol. 100, 35-39 (1985).

19. Bruins, B.G., Scharloo, W. \& Thörig, G.E.W. The harmful effect of light on 


\section{RESEARCH ARTICLES}

Drosophila is diet-dependent. Insect Biochem. 21, 535-539 (1991).

20. Levinson, H.Z., Levinson, A.R. \& Offenberger, M. Effect of dietary antagonists and corresponding nutrients on growth and reproduction of the flour mite (Acarus siro L). Experientia 48, 721-729 (1992).

21. Du, C. \& Nickerson, K.W. Insecticidal activity of avidin. Abstr. $1995 \mathrm{Mtg}$. Soc. Invertebr. Pathol., p. 70 (1995).

22. Hood, E. E. et al. Commercial production of avidin from transgenic maize: characterization of transformant, production, processing, extraction and purification. Molec. Breed. 3, 291-306 (1997).

23. Hood, E.E., Kusnadi, A., Nikolov, Z. \& Howard, J.A. Molecular farming of industrial proteins from transgenic maize. In Chemicals via higher plant bioengineering (eds Shahidi, F. et al.) 127-147 (Kluwer Academic/Plenum Publishers, New York, NY; 1999).

24. Watson, S.A. \& Ramstad, P.E. Corn: chemistry and technology. (Am. Asso. Cereal Chem., St. Paul, MN; 1987)

25. Demianyk, C.J. \& Sinha, R.N. Effect of infestation by the larger grain borer, Prostephanus truncatus (Horn), and the lesser grain borer, Rhyzopertha dominica (F.) (Coleoptera: Bostrichidae), on stored corn. Environ. Entomol. 16, 618-624 (1987)

26. Arbogast, R.T. \& Mullen, M.A. Insect succession in a stored-corn ecosystem in southeast Georgia. Ann. Entomol. Soc. Am. 81, 899-912 (1988).

27. Tigar, B.J., Key, G.E., Flores-S, M.E. \& Vazquez-Arista, M. Field and post-maturation infestation of maize by stored product pests in Mexico. J. Stored Prod. Res. 30, 1-8 (1994).

28. Tigar, B.J., Osborne, P.E., Key, G.E., Flores-S, M.E. and Vazquez-A, M. Insect pests associated with rural maize stores in Mexico with particular reference to Prostephanus truncatus (Coleoptera:Bostrichidae). J. Stored Prod. Res. 30, 267-281 (1994).

29. Wright, V.F. World distribution of Prostephanus truncatus. In Proc. GASGA Workshop on the Larger Grain Borer, Prostephanus truncatus. (Tropical Products Institute, Slough, UK (Deutsche Gesellschaft fur Technische Zusammenarbeit, Eschborn, Germany:); 1984), pp. 11-16.

30. Samols, D. et al. Evolutionary conservation among biotin enzymes. J. Biol. Chem. 263, 6461-6464 (1988)

31. Richards, A. National survey of stored-product insects in the United States1996. (unpubl. document, available from Insects Limited, Inc., Indianapolis, IN; 1997).

32. Knowles, J.R. The mechanism of biotin-dependent enzymes. Annu. Rev. Biochem. 58, 195-221 (1989).

33. Miura, K., Takaya, T. \& Koshiba, K. The effect of biotin deficiency on the biosynthesis of the fatty acids in a blowfly, Aldrichina grahami, during metamorphosis under aseptic conditions. Arch. Int. Physiol. Biochim. 75, 65-76 (1967).

34. Watanabe, T. Dietary biotin deficiency affects reproductive function and prenatal development in hamsters. J. Nutr. 123, 2101-2108 (1993).
35. Baez-Saldana, A., Diaz, G., Espinoza, B. \& Ortega, E. Biotin deficiency induces changes in subpopulations of spleen lymphocytes in mice. Am. J. Clin. Nutr. 67, 431-437 (1998).

36. Pai, C.H. \& Lichstein, H.C. Observations on the use of avidin in bacteriological media. Proc. Soc. Exp. Biol. Med. 116, 197-200 (1964).

37. Pei, R. \& Wright, L.D. Heat stability of avidin and avidin-biotin complex and influence of ionic strength and on affinity of avidin for biotin. Proc. Soc. Exp. Biol. Med. 117, 341-344 (1964).

38. Durance, T.D. Residual avidin toxicity in cooked egg white assayed with improved sensitivity. J. Food Sci. 56, 707-709, 729 (1991).

39. González, M., Argaraña, C.E. \& Fidelio, G.D. Extremely high thermal stability of streptavidin and avidin upon biotin binding. Biomolec. Engineering 16, 67-72 (1999).

40. Murray, I. \& Williams, P.C. Chemical principles of near-infrared technology. In Near-infrared technology in the agricultural and food industries. (eds Williams, P. C. \& Norris, K.H.) 17-34 (Am. Assoc. Cereal Chem., Inc., St. Paul, MN 1990).

41. Dowell, F.E., Throne, J.E. \& Baker, J.E. Automated nondestructive detection of internal insect infestation of wheat kernels by using near-infrared reflectance spectroscopy. J. Econ. Entomol. 91, 899-904 (1998).

42. Dowell, F.E., Throne, J.E., Wang, D. \& Baker, J.E. Identifying stored-grain insects using near-infrared spectroscopy. J. Econ. Entomol. 92, 165-169 (1999).

43. McGaughey, W.H. Insect resistance to the biological insecticide Bacillus thuringiensis. Science 229, 193-195 (1985).

44. Throne, J.E. Life history of immature maize weevils (Coleoptera: Curculionidae) on corn stored at constant temperatures and relative humidities in the laboratory. Environ. Entomol. 23, 1459-1471 (1994).

45. Wright, E.J. \& Cartledge, A.P. Effect of food volume and photoperiod on initiation of diapause in the warehouse beetle, Trogoderma variabile Ballion (Coleoptera: Dermestidae). In Proc. Sixth Intl. Working Conf. on StoredProduct Protection, Canberra, Australia, Vol. 1 (eds Highley, E. Wright, E.J., Banks, H. J. \& Champ, B.R.) 613-616 (CAB International, Wallingford, UK; 1994).

46. Bell, C.H. A review of diapause in stored-product insects. J. Stored Prod. Res. 30, 99-120 (1994).

47. Steel, R.G.D., and J.H. Torrie. Principles and Procedures of Statistics with Special Reference to the Biological Sciences. McGraw-Hill Book Company, Inc., New York. 481 pp. (1960).

48. SAS Institute. SAS/STAT User's guide. Version 6, Edn. 4. (SAS Institute Inc., Cary, NC; 1990).

49. Finney, D.J. Probit analysis: a statistical treatment of the sigmoid response curve. (Cambridge University Press, London; 1964).

50. LeOra Software. POLO-PC Probit and Logit Analysis. (LeOra Software, Berkeley, CA; 1994). 